\title{
The Effect of Brand Equity on Consumer Purchase Decision: The Case of Cell Phone in Ethiopia
}

\author{
Bezayit Melese Feyisa \\ School of Graduate Studies, St. Mary’s University Addis Ababa, Ethiopia \\ Daniel Basazen Beyene \\ Yom Postgraduate College, Addis Ababa, Ethiopia
}

\begin{abstract}
The primary objectives of the study were to investigate the effect of brand equity on consumers purchase decision of cell phone in Addis Ababa by utilizing Aaker's customer-based brand equity model. Four dimensions of brand equity model posited by David Aaker were used in order to conduct the investigation via quantitative research Approach, where descriptive and explanatory research design was applied. Samples of 404 respondents from Addis Ababa were selected by a convenience sampling method and 355 valid data was collected through a structured questionnaire with $88 \%$ response rate. Statistical analysis has been conducted using statistical process for social science. Descriptive analysis such as frequency, mean and standard deviation has been used to interpret the result. Furthermore, correlation and regression analysis has been performed. While performing the research, the reliability and validity of the instrument has been verified. Apart from that, the fulfillment of basic assumption for correlation and regression analysis has been conducted. The results of multiple regression analysis also revealed that the four dimensions have a positive influence on consumers purchase decision of cell phone. Among those dimensions, brand Awareness and perceived quality had the strongest positive significant influence on consumers purchase decision of cell phone respectively.
\end{abstract}

Keywords: brand, Brand Equity, Brand awareness, brand association, brand loyalty, perceived quality, Purchase decision.

DOI: $10.7176 / \mathrm{JMCR} / 78-01$

Publication date: April $30^{\text {th }} 2021$

\section{INTRODUCTION}

The Ethiopia Telecom industry is entering a new era. Ethiopia was one of the last countries in Africa to allow its national telecom a monopoly on all telecom services including fixed, mobile, internet and data communications. For many years Ethio Telecom's monopolistic control stifled innovation, restricted network expansion and limited the scope of services on offer. However, in June 2019 the government approved legislation which will open the market to competition and provide much needed foreign investment. The process to part-privatize Ethio Telecom advanced in September 2019 when the company was audited, while two licenses are expected to be offered to two international operators by the end of the year (Ethio telecom 2019). This indicates that following the privatization different cell phone companies will enter to the market and these needs of building, measuring, and sustaining brand equity of cell phone brands to withstand the completion, to earn superior profit, perform as well at exporting. To do so, the positive or negative value of the existing cell phone brands has to be measured scientifically in the context of consumers so that appropriate marketing intervention could be developed.

Prominent marketing authors like Kotler and Keller (2012) described that the short-term financial benefit versus the long-term brand building exercise will be evaluated based on a perpetual measurement of brands. Obviously, marketers thus, due to these and other facts consider not only building and sustaining of brand equity as strategic concern of marketing intangibles but also the measurement of brand equity as strategic concern in their marketing endeavors. There is no research conducted in this area and hence creating a research gap.

Thus, this study will shed light and narrow literature gap by empirically measuring the dimensions of brand equity of cell phone markets of Ethiopia (in case of Addis Ababa) to determine the effect of the most popularly adopted brand equity dimensions on purchase decision.

\subsection{Statement of The Problem}

According CIA world fact book 2019 ranked Countries in the number of Mobile phone users and Ethiopia is ranked 24 in the world by having 62.6 million subscribers. The report of Digital in 2018 released also shows there are 16.4 million Internet users in Ethiopia with Internet penetration at 15 percent. According to the report, much of this year's growth in Internet users has been driven by more affordable smart phones and mobile data plans. Currently, the Ethiopia telecom industry entering in new era due to partial privatization of the sector following this competition in the market will become fierce and thus, the need for marketers to differentiate their cell phone brands has become increasingly significant. Companies are in the race for attracting their customer's attention, and one of the vital means to achieve this goal is distinction through branding. Brands play a significant role in 5 
purchase decision and also define a customer, its social status and way of living. This can be seen when customer is purchasing a cell phone, he or she has many alternatives. All offering almost with the same features and benefits but there are many underlying reasons which make the consumer to prefer one brand over the other (Terence Shimp, 2013). Several studies have been conducted to underlying the reason why consumer prefer one brand over the other and the source of brand equity for purchase intention. A study conducted in Turkey by (Gokhan and Burc 2015) indicates that brand Awareness and Association are the most significant factors which influence consumers purchase intension. On the other hand, the study conducted in paksitan by (Mohammed and Sameen 2016) indicate that brand Awareness and brand quality are not the most significant factors for consumer purchase intension rather drivers like brand loyalty and Association are significant factors for purchase intension. In Our case, cell phone industry is growing and due to partial privatization of the telecom sector companies will enter to the market and these needs of building, measuring, and sustaining brand equity of cell phone brands to withstand the completion, to earn superior profit, perform well. To do so, the positive or negative value of the existing cell phone brands has to be measured scientifically in the context of consumers so that appropriate marketing intervention could be developed and acted up on. However, there is a lack of research publication on the source of brand equity in the case of cell phone in Ethiopia. Thus, this research has been attempting the effect of brand equity components on customer purchase decision or to what extent Brand equity affects purchase decision and to fill the gaps in marketing efforts of marketing professionals and companies while presenting their offering to the consumers.

\subsection{Research Questions}

\subsubsection{Main Question}

What is the influence of brand equity on consumer purchase decision of cell phone in the case of Addis Ababa?

1.2.2 Sub Questions

1. To what extent brand Awareness influence the consumer purchase decision of cell phone?

2. How does brand Association influence the consumer purchase decision of cell phone?

3. To what extent Perceived Quality influence, the consumer purchase decision of cell phone?

4. Does brand Loyalty influence the consumer purchase decision of cell phone?

\subsection{Objectives of The Study}

This study has the following general and specific objectives.

\subsubsection{General Objective}

The general objective of the study was to assess the effect of brand equity on consumer purchase intention of cell phone in Addis Ababa.

\subsubsection{Specific Objectives}

To achieve the general objective of the study, the following specific objectives are designed and are as follows:

1. To examine the effect of brand awareness on consumers purchase decision.

2. To assess the relationship between brands association and consumers purchase decision.

3. To analyze the effect of perceived quality on consumers purchase decision.

4. To investigate the effect of brand Loyalty on consumers purchase decision.

\section{LITERATURE REVIEW}

\subsection{Brand Equity}

Different authors have defined the term brand equity from different perspective and varies methodologies have been developed for measuring brand equity is numerous in extant literature. The meaning, boundaries and measures of brand equity is still contentious. There is no consensus up on the measurement tools and theoretical perspectives whether brand equity refers to a value of brand name or the value of brand which is denoted by a brand name. For example, the net difference approach between a target brand and a fictitious/generic/private label brand reflects the value of a brand name, not the value of a brand. Rogers et. al (2008).

Farquhar (1989) defined brand equity as "the value added by the brand to the product" and by Srivastava and Shocker (1991) as "incremental utility or value added to a product by its brand name." Aaker (1991) defines brand equity as "a set of brand assets and liabilities linked to a brand, its name and symbol that add to or subtract from the value provided by a product or service to a firm and/or to that firms customer."

Keller (1993) defines brand equity as the "differential effect of brand knowledge on consumer response to the marketing of the brand. Brand knowledge is the full set of brand associations linked to the brand in the longterm consumer memory. According to Kamakura W. and Russel G (1993) CBBE occurs when the consumer is familiar with the brand and holds some favorable, strong, and unique brand associations in memory. On the other hand, Clow and Baack (2005) also states, brand equity are the brand features that characterize the brand as unique in the market place.

Based on the way they defined consumer brand equity incorporate different components. But the framework and definition most frequently cited and studied are Aaker (1991) which incorporates multi- dimensional approach 
in knowing, distinguishing, and differentiating brands that consists of mental assets and liabilities. This model incorporates five dimensions that form the consumer- based brand equity namely; "brand loyalty," "brand awareness," "perceived quality," "brand associations," and "other brand assets."

Scholars such as Keller (1993), Motameni and Shahrokhi (1998), Prasad and Dev (2000), Yoo and Donthu (2001), Pappu et al. (2005), and Buil et al. (2008) adopted this approach in their studies to clearly incorporate the consumers idea and the psychological factors underlying brand equity.

Aaker's four basic brand equity dimensions: brand awareness, brand association, perceived quality and brand loyalty have been used to prepare the main framework of this research, and are discussed in the following parts of the article.

\subsection{Brand Equity Dimension and Consumer Buying Behavior}

\section{A) Brand Awareness}

The major consumers brand equity drivers according to (Aaker, 1991; Agarwal \& Rao 1996; Kapferer, 1991; Keller, 1993; Krishnan, 1996). Brand awareness is all about communication. Aaker (1991) explains the awareness and recall of a name: "A name is like a special file folder in the mind which can be filled with name-related facts and feelings. Without such a file readily accessible in memory, the facts and feelings become misfiled, and cannot be readily accessed when needed." This is measured by the ability of consumers to recall and recognize brands for a certain category.

The ability is determined by the strength of the brand nodes in memory. Brand recalls the ability to retrieve the brand from the memory when some cues are provided. Brand recognition is the consumers' ability to confirm prior exposure when a brand is given as cues (lovely professional's university)

B) Brand Association

Aaker state that brand association represents anything linked to the memory of a brand. When the associations become signification, it forms brand image which shows the consumers perception towards the brand from the associations gathered in their memory. Brand association can be an outcome of functional or symbolic characteristics of a brand. Usually, consumers are found to link a brand with features such as technological advancements, innovativeness, distinctiveness, status, and overall excellence in product or service performance.

Aaker (1991, 1992, and 1996) delineated brand associations as assets that can provide value for companies in several ways. First, brands association can provide an important basis for differentiation. Associating the brand name can provide a unique and distinguishable attribute that will stand the brand differently. Second, brand association can represent a basis for purchase decision and brand loyalty by providing product attributes or customer benefits that provides a specific reason to buy and use a brand. Third, it can also influence purchase decision by ascribing credibility \& confidence to a brand by stimulating positive feeling that are transferred to a brand.

Fourth, brand association create value through creating a positive feeling during the use experience, serving to transform a product into something different than what it might otherwise be. Finally, it provides the basis for an extension and associations can serve to summarize a set of facts and specification that otherwise would be difficult for the customer to process and access, and expensive for the firm to communicate.

C) Brand Loyalty

Aaker (1992) labeled brand loyalty is prime enduring dimension of brand equity. Contrary to the brand awareness and brand association brand loyalty may resulted from a perpetual purchase of the brands by the same consumer over time. Brand loyalty is resistance to switch the brand, rather, consumers continue to buy the brand even in the face of competitors with superior features, and price, and convenience, substantial value exists in the brand and perhaps in its symbol and slogans. Brand loyalty is at the of heart brand equity. According to Aaker's brand equity model brand loyalty reduces marketing costs, boost trade leverage, attract new customers and offer time to respond to competitive threats.

D) Perceived Quality

As per Aaker (1991) perceived quality consumers expectation about particular product or company. In other side Swinker and Hines (2006) classified perceived quality into four categories: intrinsic, extrinsic, appearance and performance. Boulding (1993) argued that quality is directly influenced by perceptions. 


\subsection{Conceptual Framework of the Study}

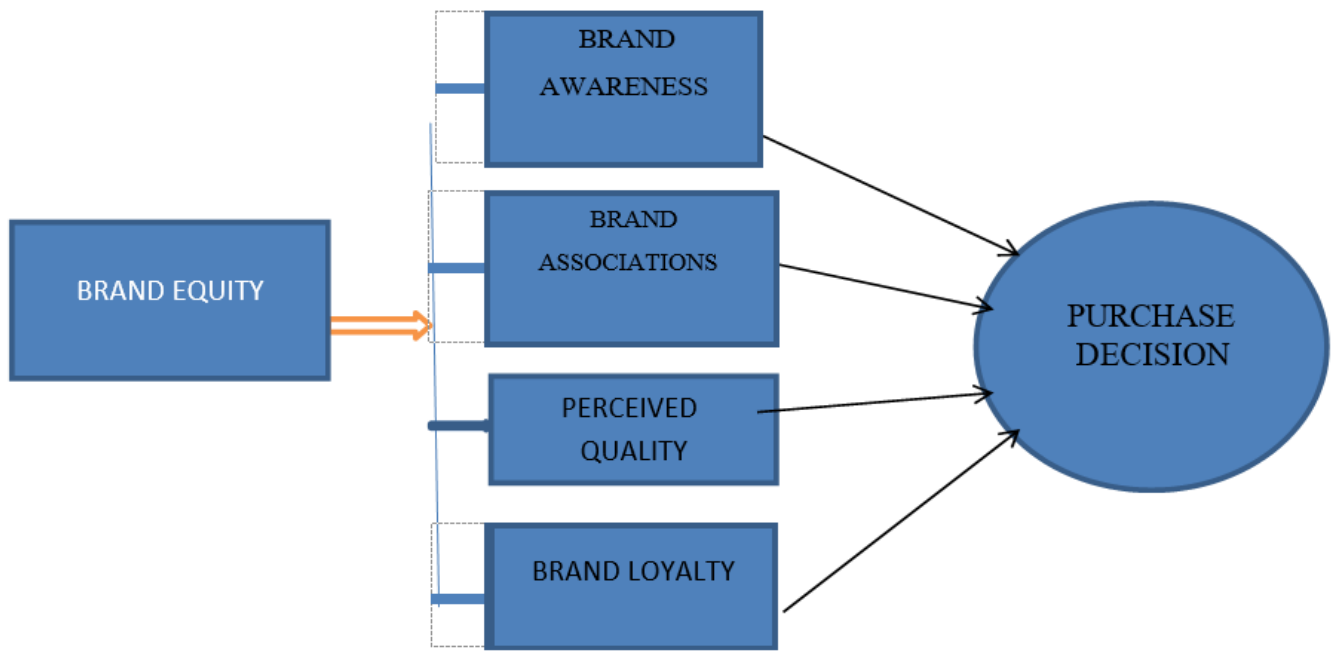

Figure1: Conceptual Framework of the study (Aaker, 1991)

\subsection{Hypothesis of The Study}

To test the relationship between brand equity dimensions and Purchase decision the following hypothesis have been developed:

Brand Awareness; - the major consumers brand equity drivers according to (Aaker, 1991; Agarwal \& Rao 1996; Kapferer, 1991; Keller, 1993; Krishnan, 1996). Aaker (1991) explains the awareness and recall of a name: "A name is like a special file folder in the mind which can be filled with name-related facts and feelings.

Without such a file readily accessible in memory, the facts and feelings become misfiled, and cannot be readily accessed when needed." This is measured by the ability of consumers to recall and recognize brands for a certain category and brand awareness provides a foundation for brand equity. In the literature it is observed that brand awareness positively affecting purchase decision.

H1. Brand awareness has a significant positive effect on consumers purchase decision.

Brand Association: - Aaker state that brand association represents anything linked to the memory of a brand. When the associations become signification, it forms brand image which shows the consumers perception towards the brand from the associations gathered in their memory. Brand Association keller (2003) are information in the form of nodes which contains meaning for consumers. In the literature it is observed that brand association positively affecting purchase decision.

H2. Brand association has a significant positive effect on consumers purchase decision.

Perceived Quality: - it refers to the consumer's judgment (perception) about product's overall excellence or superiority with reference to substitutes (Aaker, 1991). In the literature it is observed that perceived quality of the brand positively affecting purchase decision.

H3. Perceived quality has a significant positive effect on consumers purchase decision.

Brand Loyalty: - Aaker $(1991,1992)$ labeled brand loyalty is prime enduring dimension of brand equity. Brand loyalty is resistance to switch the brand, rather, consumers continue to buy the brand even in the face of competitors with superior features, and price, and convenience, 30 Substantial value exists in the brand and perhaps in its symbol and slogans. Brand loyalty is at the of heart brand equity.

H4. Brand loyalty has a significant positive effect on consumers purchase decision.

Consumer-based Brand Equity has been considered as a condition or prerequisite for the election or preference of a brand, which subsequently affects the purchase decision. Several studies point out the positive relationship between the components of Brand Equity and the purchase decision (Vakratsas and Ambler, 1999; Myers, 2003). Brand Equity is the positive differential effect that knowing the brand name has on customer response to the product or service (Kotler \& Armstrong, 2008). Brand equity can be evaluated through, Brand loyalty, Brand awareness, Perceived quality, Brand association. The implications of model help in managing brand equity and consider sensitive value to make informed decisions about brand- building activities. Brand equity is important at purchasing time as it influence customers and complete with the competitor's attraction.

H5. Brand Equity has a significant positive effect on consumers purchase decision.

\section{METHODOLOGY}

To analyses the impact brand equity elements may have on buying behavior, a five -point likert scale questionnaire was developed from the previous studies conducted by Yoo and Donthu. The likert scale ranged from "5" 
signifying "Strongly Agree" to "1" meaning "Strongly Disagree". With convenience sampling primary data were collected from 404 self- administered questionnaires, 355 were finalized as the rest were discarded mainly due to the incompletion of data.

Since the research focuses on the buying behavior of cell phone user, respondents. The questionnaire was constructed to have two sections. The first section is aimed to gather general information about the respondents as well as the smartphone brand(s) they use or prefer. On the other hand, the following section, which is specifically integral to the main purpose of the research, was designed using pre- determined variables related to brand equity dimensions (i.e., brand awareness, perceived quality, brand loyalty and brand association) and consumer buying behavior. The collected data was further analyzed using Statistical Package Software for Social Sciences (SPSS 24.0).

\section{RESULTS AND DISCUSSION}

\subsection{Current Cell Phone Brands of Respondents}

From the table 1 below, when asked the brand of their current mobile phone respondents answered Samsung (54.9\%), Techno (13.5\%) and Huawei (8.2\%) were the top three bands the respondents currently own. In addition, Itel $(0.8 \%)$, Nokia $(1.1 \%)$ and SMADL $(2.8 \%)$ were found to be the least three favored brands owned by the respondents.

Table 1 Current Cell phone brands of respondents

\begin{tabular}{|c|c|c|}
\hline Cell phone brand & Frequency & Percent \\
\hline Samsung & 195 & 54.9 \\
\hline IPhone & 19 & 5.4 \\
\hline Nokia & 4 & 1.1 \\
\hline Techno & 48 & 13.5 \\
\hline Huawei & 29 & 8.2 \\
\hline SMADL & 10 & 2.8 \\
\hline Itel & 3 & .8 \\
\hline LG & 15 & 4.2 \\
\hline Others & 26 & 7.3 \\
\hline Total Source: survey result, 2020 & 100 \\
\hline \multicolumn{2}{|c}{}
\end{tabular}

\subsection{Pearson Correlation Result of The Variables}

Results show the correlation between four factors i.e., Brand Awareness, brand Association, perceived quality, and brand loyalty with the decision to buy a cellphone. Accordingly, all factors have a positive and significant relationship with the purchase decision of cell phone. However, the degree of correlation among the factors is different with the highest correlation value of Brand Awareness $(0.689)$ followed by brand loyalty $(0.650)$, brand Association (0.55) and perceived quality (0.509) of the cell phone.

Table 2 Correlation coefficients

\begin{tabular}{|l|c|l|c|c|l|l|}
\hline \multicolumn{2}{|c|}{} & $\begin{array}{l}\text { Purchase } \\
\text { Decision }\end{array}$ & $\begin{array}{c}\text { Brand } \\
\text { Awareness }\end{array}$ & $\begin{array}{c}\text { Brand } \\
\text { Association }\end{array}$ & $\begin{array}{l}\text { Perceived } \\
\text { Quality }\end{array}$ & $\begin{array}{l}\text { Brand } \\
\text { Loyalty }\end{array}$ \\
\hline \multirow{2}{*}{$\begin{array}{l}\text { Purchase } \\
\text { Decision }\end{array}$} & Pearson Correlation & 1 & $.689^{* *}$ & $.555^{* *}$ & $.509^{* *}$ & $.650^{* *}$ \\
\cline { 2 - 8 } & Sig. (2-tailed) & & .000 & .000 & .000 & .000 \\
\cline { 2 - 8 } & $\mathrm{N}$ & 355 & 355 & 355 & 355 & 355 \\
\hline
\end{tabular}

**. Correlation is significant at the 0.01 level (2-tailed)

Source: survey result, 2020

\subsection{Descriptive Analysis of Independent and Dependent Variables}

\subsubsection{Descriptive Statistics of Brand Awareness}

According to Keller (2003) brand awareness is "the customers"e ability to recall and recognize the brand as reflected by their ability to identify the brand under different conditions and to link the brand name, logo, symbol, and so forth to certain associations in memory." Accordingly, the respondents were asked 6 questions related to brand awareness. The Table 3 below present's respondents result of brand awareness with mean and standard deviation values for each item. 
Table 3 Brand Awareness Descriptive Statistics

\begin{tabular}{|c|c|c|c|}
\hline & $\mathbf{N}$ & Mean & $\begin{array}{l}\text { Std. } \\
\text { Deviation }\end{array}$ \\
\hline BAW1 - I am aware of my cell phone brand & 355 & 4.0704 & 1.04859 \\
\hline BAW2- I can recognize my cell phone brand among computing brands & 355 & 3.8930 & 1.01114 \\
\hline $\begin{array}{l}\text { BAW3-Whenever I think about cellphones the brand I use come to my mind } \\
\text { first }\end{array}$ & 355 & 4.0056 & 1.10468 \\
\hline BAW4-I can easily recall some of the features of my brand & 355 & 3.8479 & .98547 \\
\hline BAW5-I can recognize the symbol or logo of my Cell phone brand & 355 & 4.0366 & 1.01476 \\
\hline BAW6-My awareness of cell phone brand influences my purchase decisions & 355 & 4.0873 & 1.00605 \\
\hline BAW & 355 & 3.9901 & .87825 \\
\hline
\end{tabular}

Source: survey result, 2020

As indicated in the above table the mean scores of brand awareness attributes for all the six items ranges from 3.84 to 4.08 which indicates that respondents the level of awareness influence when they buying decision of the cell phone. The overall mean score of brand awareness attributes was calculated to be 3.99

\subsubsection{Descriptive Statistics of Brand Association}

Brand association consists of "all brand related thoughts, feelings, perceptions, images, experiences, beliefs, attitudes and is anything linked in memory to a brand (Kotler and Keller 2006, p.188). Hence, 7 items related to brand association asked to the respondents. Table 8 shows the analysis about brand association mean and standard deviation.

Table 4 Brand Association Descriptive Statistics

\begin{tabular}{|l|c|c|c|}
\hline & N & Mean & $\begin{array}{c}\text { Std. } \\
\text { Deviation }\end{array}$ \\
\hline BAS1:- The brand of mobile phone I use assists me to attain the type of life I desire for & 355 & 3.6254 & 1.10363 \\
\hline BAS2:- I can link and associate between my life experiences and the brand I use. & 355 & 3.7408 & 1.12767 \\
\hline BAS3:- I think others form a judgment regarding me with the type of brand I use & 355 & 3.6789 & 1.13171 \\
\hline BAS4:- My cell phone brand is interesting & 355 & 3.7606 & 1.04780 \\
\hline BAS5:- The company that makes my cell phone brand has credibility & 355 & 3.7014 & .72942 \\
\hline $\begin{array}{l}\text { BAS6:- My cell phone brand has a personality that distinguish itself from } \\
\text { competitor's brand }\end{array}$ & 355 & 3.7577 & .75008 \\
\hline $\begin{array}{l}\text { BAS7:- I have a clear image of the type of people who use my type of cell phone } \\
\text { brands }\end{array}$ & 355 & 3.6930 & .76197 \\
\hline \multicolumn{1}{|c|}{ BAS } & 3.7082 & .62962 \\
\hline
\end{tabular}

Source: survey result, 2020

As indicated in the above table, the mean scores of brand association for all the seven items ranges from 3.62 to 3.76 which indicates that the cell phone they used were interesting got the highest mean score 3.76 , where as they assist the type of life, they desire has got the least mean score value of 3.62. The overall mean score of brand association was calculated to be 3.70 .

\subsubsection{Descriptive Statistics of Perceived Quality}

Perceived quality is the customer's judgment about a product's overall excellence or superiority that is different from objective quality (Aaker, 1996). Since it's impossible for consumers to make complete and correct judgments of the objective quality, they use quality attributes that they associate with quality (Zeithaml, 1988). With this idea, 6 items related to perceived quality were raised to the respondents and the results of the Mean score and the Standard deviation.

Table 5 Perceived quality Descriptive Statistics

\begin{tabular}{|l|c|c|c|}
\hline & $\mathbf{N}$ & Mean & $\begin{array}{c}\text { Std. } \\
\text { Deviation }\end{array}$ \\
\hline PQ1 :- I'm satisfied with the software quality of my brand & 355 & 3.6761 & 1.00528 \\
\hline PQ2 :- My cell phone brand has consistent performance & 355 & 3.7127 & .97235 \\
\hline PQ3 :- The battery life of my brand lasts longer & 355 & 3.8141 & 1.00525 \\
\hline $\begin{array}{l}\text { PQ4 :- The company who offers my cell phone brands offers reliable and } \\
\text { trustworthy product }\end{array}$ & 355 & 3.7070 & .96775 \\
\hline PQ5 :- The aesthetic appeal of my brands is stylish & 355 & 3.7211 & .92271 \\
\hline PQ6 :- My cell phone brand is well made PQ & 355 & 3.9070 & .97993 \\
\hline \multicolumn{1}{|c|}{ PQ } & 355 & 3.7563 & .81948 \\
\hline
\end{tabular}

Source: survey result, 2020

As indicated in the above table, the mean scores of perceived qualities for all the six items ranges from 3.9 to 3.67 the cell phone brand they own is well made has got the highest mean score. The overall mean score of 
perceived quality was calculated to be 3.75 .

\subsubsection{Descriptive Statistics of Brand loyalty}

Brand Loyalty is a core dimension of brand equity. Aaker (1991, p.39) defines brand loyalty as "the attachment that a customer has with a brand." Based on this definition 6 item related to brand loyalty was raised to the respondents to be answered. The result is presented in Table 4.8 below:

Table 6 Brand Loyalty Descriptive Statistics

\begin{tabular}{|c|c|c|c|}
\hline & $\mathbf{N}$ & Mean & $\begin{array}{c}\text { Std. } \\
\text { Deviation }\end{array}$ \\
\hline BL1.If I buy cell phone, my cell phone brand would be my first $p$ & 355 & 4.0141 & 1.04548 \\
\hline BL2.I am loyal to my mobile brand & 355 & 3.7915 & .89660 \\
\hline $\begin{array}{l}\text { BL3.I will not buy other brands of cell phones if my current brands not availability the } \\
\text { store }\end{array}$ & 355 & 3.7690 & 1.24540 \\
\hline BL4.I say positive things about my brand to other peoples & 355 & 3.9634 & .95451 \\
\hline BL5.I recommended my cell phone brand to anyone who seeks m & 355 & 3.8592 & .90347 \\
\hline $\begin{array}{l}\text { BL6.I would still like to buy the same brand that I already have been if another brand } \\
\text { has the same features }\end{array}$ & 355 & 3.7972 & 1.01875 \\
\hline BL & 355 & .8657 & .86546 \\
\hline
\end{tabular}

Source: survey result, 2020

As depicted in Table 6 above, the mean value of brand loyalty is 3.86 and the item state that "When decide buying cell phone the brand they own currently would be my first choice." scored the highest among the list of items related to brand loyalty with a mean score of 4.04 while the respondents gave the least score of 3.791 to the item "I am loyal to the cell phone brand."

\subsubsection{Descriptive Statistics of Purchase Decision}

In order to test the respondents' Purchase decision, 4 items were asked to the respondents to answer. It shows the Mean score and Standard deviation analysis regarding the purchase decision of the respondents.

Table 7 Purchase Decision Descriptive Statistics

\begin{tabular}{|l|r|r|r|}
\hline & $\mathrm{N}$ & Mean & $\begin{array}{r}\text { Std. } \\
\text { Deviation }\end{array}$ \\
\hline $\begin{array}{l}\text { PD1. My purchase decision depends upon how others think about me with the } \\
\text { type of brand I use }\end{array}$ & 355 & 3.8704 & .95082 \\
\hline \begin{tabular}{l|l|} 
PD2. My awareness regarding a mobile brand guides my purchase decision \\
PD3. The overall assessment of the quality of brand affects my purchase decision
\end{tabular} & 355 & 3.9324 & .93636 \\
\hline PD & 355 & 3.8986 & .96602 \\
\hline \multicolumn{1}{|l|}{ PD4. In future, I will buy the same brand that I already have } & 355 & 3.8979 & .999251 \\
\hline
\end{tabular}

Source: survey result, 2020

As indicated in the above table the mean scores of purchase decision for all the four items ranges from 3.93 to 3.87 which is the awareness regarding a mobile brand guides my purchase decision with mean value of 3.89 , The decision depends up on how other think about the brand they use has got the least mean score value of 3.87. The overall mean score of purchase decision was calculated to be 3.89 .

\subsection{Multiple Regressions Analysis}

In this study, there are four independent variables namely Brand Awareness, brand Association, perceived quality, and brand loyalty with the decision to buy a cellphone. To test the effects of these variables on the decision to buy a cell phone, the study used the multiple regression analysis. The table below shows the multiple regression result between four independent variables and the purchase decision to a cell phone device in Addis Ababa. It indicates that all the four independent variables (Brand Awareness, brand Association, perceived quality, and brand loyalty) combined significantly influence the consumers Purchase decision of cell phone devices.

Table 8 Coefficient Matrix

\begin{tabular}{|c|c|c|c|c|c|}
\hline \multirow[t]{2}{*}{ Model } & \multicolumn{2}{|c|}{ Unstandardized Coefficients } & \multirow{2}{*}{\begin{tabular}{|r|}
$\begin{array}{l}\text { Standardized } \\
\text { Coefficients }\end{array}$ \\
Beta \\
\end{tabular}} & \multirow[t]{2}{*}{$\mathrm{T}$} & \multirow[t]{2}{*}{ Sig. } \\
\hline & $\mathrm{B}$ & Std. Err & & & \\
\hline (Constant) & .385 & .188 & & 2.051 & .041 \\
\hline BAW & .329 & .059 & .365 & 5.590 & .000 \\
\hline BAS & .219 & .058 & .174 & 3.764 & .000 \\
\hline PQ & .242 & .038 & .250 & 6.362 & .000 \\
\hline $\mathrm{BL}$ & .124 & .060 & .135 & 2.078 & .038 \\
\hline
\end{tabular}

Source: survey result, 2020

Table 8 presents the coefficient matrix analysis which is based on the four independent variables (Brand 
Awareness, Brand Association, Brand Perceived Quality and Brand Loyalty). The beta value on the coefficient table indicates level of effect each dimension has on the dependent variable which is purchase decision.

The regression coefficient explains the average amount of change in the dependent variable that is caused by a unit change in the independent variable. The larger value of Beta coefficient an independent variable has, brings the more support to the independent variable as the more important determinant in predicting the dependent variable.

The regression model from table 8 above result shows that keeping other variables constant, a one unit increase in Brand Awareness will bring a 0.329 unit increase in the purchase decision of cell phone In Addis Ababa, a one unit increase in Brand Association will bring a 0.219 unit increase impact on purchase decision of cell phone in A.A, a one unit increase in Brand Perceived Quality will bring a 0.242 unit increase in purchase decision of cell phone in Addis Ababa and a one unit increase of Brand Loyalty will cause a 0.124 unit increase in purchase decision of cell phone in Addis Ababa. It indicates that all the four independent drivers of brand equity significantly influence the consumer purchase decision cell phone. The leading factor is brand Awareness preceding with perceived quality.

\subsection{Regression Equation}

Pallant J. (2005) stated while evaluating the research model and analyzing the predictive ability of the independent variables, formulating regression equation is essential. As per the scholar, the values of $\beta$ under unstandardized coefficients and the constant are considered. As a result, the equation is expressed as: -

$\mathrm{Y}($ Purchase decision $)=0.385(\mathrm{y}$ intercept $)+(0.329)$ Brand Awareness $+(0.219)$ Brand Association $+(0.242)$ Brand Perceived Quality + (0.124) Brand Loyalty

\subsection{Hypothesis Testing Summary}

\begin{tabular}{|c|c|c|c|}
\hline Hypothesis & Description & $\begin{array}{l}\text { Regression } \\
\text { Result }\end{array}$ & Conclusion \\
\hline $\mathrm{H} 1$ & $\begin{array}{l}\text { Brand Awareness has a positive and significant } \\
\text { effect on purchase decision of cell phone }\end{array}$ & $\begin{array}{c}\beta=.365 \\
\text { Sig }=0.000\end{array}$ & Supported \\
\hline $\mathrm{H} 2$ & $\begin{array}{l}\text { Brand Association has a positive and significant } \\
\text { effect on purchase decision of cell phone }\end{array}$ & $\begin{aligned} \beta & =.174 \\
\text { Sig } & =0.000\end{aligned}$ & Supported \\
\hline $\mathrm{H} 3$ & $\begin{array}{l}\text { Perceived Quality has a positive and significant } \\
\text { effect on purchase decision of cell phone }\end{array}$ & $\begin{array}{c}\beta=.250 \\
\text { Sig }=0.000\end{array}$ & Supported \\
\hline H4 & $\begin{array}{l}\text { Brand Loyalty has a positive and significant effect } \\
\text { on purchase decision of cell phone }\end{array}$ & $\begin{aligned} \beta & =.135 \\
\text { Sig } & =0.038\end{aligned}$ & Supported \\
\hline
\end{tabular}

Source: Own survey, 2020

\section{CONCLUSION \& RECOMMENDATIONS}

The objective of this research was to investigate the underlying factors that determine the purchase decision of cell phone devices. According to the study, majority of the consumers own Samsung mobile phones. According to Pearson correlation results, brand Awareness is the dominant factor affecting the decision of customer to buy cell phone. Secondly, the brand loyalty incorporated in a mobile hand set is the most important factor which is considered by the consumers while purchasing the mobile phone. However, all other influencing factors of mobile phone are not equally important. The other factors equally correlated and have moderate relationships with the decision to buy. This study used multiple regression analysis to test the effects of four independent variables on the purchase decision of cell phone device. All the four independent variables combined significantly influence the purchase decision of cell phone devices.

However, the study is not free of limitations, which could be taken into consideration to fully explore further scopes of research. More diverse range of respondents could be reached in order to enrich the data. In addition, more variables could help to analyze buying behavior of Consumer to obtain a wider view on the subject matter. If others researchers conduct on extended model of brand equity. As a result, the research may have geographical, technical and conceptual limitations. So, further and regress study in wider scope may provide a better outcome.

\section{REFERENCES}

Aaker, D.A. (1991). Managing Brand Equity. The Free Press, New York, NY. Aaker, D.A. (1996). Building Strong Brands. The Free Press, New York, NY.

Agarwal, M.K. and Rao, V.R. (1996). An empirical Comparison of Consumer-Based Measures of Brand Equity. Marketing Letters, 7(3), 237-247.

Alamor, A. and Rowley, J (2011), Antecedents of Brand Preference of Mobile Telecommunications Services, Journal of Products \& Brand Management, 20(6), 475-456.

Alan Bryman, (2008), Social Research Methods. Oxford: Oxford University Press, 3rd Edition. Anselmsson J., 
Johansson U. and Persson N., (2008), The battle of brands in the Swedish market for consumer-packaged food: A cross-category examination of brand preference and liking, Journal of Brand Management, 16(1), 6379.

Anosh muhammed, Naqvi Hamed, Ghulam Shabir (2014). Impact of brand equity on purchase Intention. Journal of Innovative Research and development, Vol 3

Bill Millilees and Dale miller, 2004), principles of corporate rebranding. European journal of Marketing Vol 42

Buil, I., de Chernatony, L. \& Martinez, E. (2008). A cross-national validation of the consumer-based brand equity scale. Journal of Product and Brand Management, 17(6), 384- 392

Boulding W., Kalra A., Staelin R. and Zeithaml V. (1993), A dynamic process model of service quality: From expectations to behavior intentions, Journal of Marketing Research 30(February): 7-27.

Bernue's A., Olaizola A. and Corcoran K.(2003), Extrinsic attributes of red meat as indicators of quality in Europe: an application for market segmentation. Food Quality and Preference 14(4): 265-76.

Boonghee Yoo, N. D. (2001). Developing and Validating a Multidimensional Consumer-Based Brand Equity Scale. Journal of Business Research, 52, PP:1-14.

Chen A.C.H. (2001). Using free Association to examine the relationship between the characteristics of brand associations, and Brand Equity. Journal of Product and Brand Management. 10 (7) PP: 439-451

Chieng Fayrene Y.L. Goi Chai Lee (2011): Customer-Based Brand Equity: A literature Review. Journal of Arts Science and Commerce, 2, issue 1, PP:33-42

Chang, P.L. \& Chieng, M.H. (2008),"Building consumer-brand relationship: A cross cultural experiential view," Psychology \& Marketing, 23, 11,pp 927-59

Cristina Calvo Porrel, N. B. (2013). Brewing the recipe for beer brand equity. European Journal of Research, PP:117.

Christodoulides, G. \& de Chernatony L. (2010). Consumer-based brand equity conceptualization and measurement Intl. Journal of Market Research, 52(1), 43-66.

Clow, K. E. \& Baack, D. (2005) Concise Encyclopedia of Advertising. New York, Haworth Press, Inc.

CORBETTA, P. (2003). Social science research:Theory, Methods and Techniques. SAGE Publications Ltd.

DeChernatory L. and McDonald M. (2003), Creating Powerful Brands: In Consumer, Service and Industrial Market, 3rd edition. Butterworth Heinemann.

Donthu, B. Y. (2001). Developing and Validating a Multidimensional Consumer-Based Brand Equity Scale. Journal of Business Research, PP:1-14.

Ethiopian Telecommunication Corporation (2005). A Background Paper on Telecom \& Telecom Statistics in Ethiopia, http://www.teleco m.net.et.

Eda Atilgan, S. A. (2005). Determinants of the brand equity: A verification approach in the beverage industry in Turkey",. Marketing Intelligence \& Planning, Vol. 23 (Iss: 3), pp.237 - 248.

Farquhar, P. H. (1989, September). Managing brand equity. Journal of Marketing Research, 24- 33.

Feldwick, P. (1995). What is brand equity anyway, and how do you measure it? Journal of the Market Research Society, 38(2), 85-104.

Hair, J. F., Anderson, R. E., \& Tatham, R. L. (1998). Multivariate data analysis (5th ed.). Upper Saddle River,NJ: Prentice-Hall.

Hansen and christence (2003); Influence of brand name on consumer decision making process. HosseinA.(2012). Conceptualization of consumer based brand equity in banking sector of Iran. Journal of consumer Marketing (15-33)

Hawkins, D., Mothersbaugh, D., \& Best, R. (2012). Consumer Behavior: Building Marketing Strategy 12th Edition.

Hyun, S. (2009). Creating a Model of Customer Equity for Chian Resturand Brand Formation. International Journal of Hospitality Management, 28 (4), PP:529-539.

Hess, Story and Danes, (2011) A three stage model of consumer relationship investment. Journal of product and brand management.

Holt, D. B. (2004). How Brands become Icons. Harvard Business Review.

Keller, K.L. (2003). Strategic Brand Management: Building, Measuring and Managing Brand Equity (2nd Ed.). Englewood Cliffs, NJ: Prentice-Hall.

Keller, K.L. (1993). Conceptualizing, Measuring and Managing Customer-Based Brand Equity. Journal of Marketing, 57, 1-22.

Kim and Kim (2005), The relationship between brand equity and firms performance. Journal of tourism management $\mathrm{p} 549-560$

Kotler P. and Keller K.L, (2012), Marketing Management, 14th edition, Pearson Prentice Hall. Kotler P., Keller, K.L., Brady, M., Goodman, M. and Hansen, T. (2009), Marketing Management, Pearson/Prentice Hall.

Kapferer J.N (2008), The strategic Brand Management: Creating and sustaining brand equity, Long Term, Kogan Page, London

Kotler, Pfoertsch. (2006). B2BBrand Management. Springer. 
Kamakura W. G. Russel (1993). Measuring Brand Value with Scanner Data. International Journal of Researchin marketing, 1o, PP:9-22

Kapferer, J. N. (1991). Strategic brand management. New York: The Free Press.

Krishnan, H. S. (1996). Characteristics of memory associations: A consumer based brand equity perspective. Intl. Journal of Research in Marketing, 13, 389-405. Elgar Publishing Limited.

Leary, M. R. (2012). Introduction to Behavioral Research Methods (6th ed.). (S. Madelyn, Ed.) Boston: Pearson Education Inc.

Leslie and Malcolm (1992) ; Creating powerful Brands page 282 Leon \& Leslie 2000, Consumer behavior P 159160

L.Rogers, B. H. (2008). Hand Book on Brand and Experience Management. Northampton: Edward

Lancaster, D. J. (2009). Selling andSales Management (8th ed.). London: Pearson Edu. Limited. Lee, J. S. \& Back, K. J. (2010) Reexamination of attendee-based brand equity. Tourism Management, 31(3), pp. 395-401.

Margaret C Campbell (2002) Building brand Equity; International Journal of Medical Marketing p208.

Motameni, R . and Shahrokhi, M. (1998). Brand equity valuation: A global perspective.

Journal of Product and Brand Management, 7(4), 275-290. McCall, M. (2002). Consumer Psychology.

Madhobi Hossain, , Kazi Md. Fahim Ahmed(2018) Impact of brand equity on the buying behavior. International Journal of Business and Management Invention (IJBMI) www.ijbmi.org PP47-54

Muhammad Amir Adam and Sameen Nasir Akber(2016) The impact of brand equity on consumer purchase decision of cell phones. Journal of European Journal of Business and Innovation Research(www.eajournals.org) pp60-133

PALLANT J. (2005) SPSS Survival Manual: A step by step guide to data analysis using SPSS for Windows. Sydney: Ligare.

Pappu, R., Quester, P. G. and Cooksey, R. W. (2005). Consumer-Based Brand Equity:

Improving the Measurement - Empirical Evidence. Journal of Product \& Brand Management, 14(3), $143-154$.

Prasad, K., \& Dev, C. S. (2000). Managing hotel brand equity: A customer-centric framework for assessing performance. Cornell Hotel and Restaurant Administration Quarterly, June, 22- 31.

Raham S. E. (2013), A Study of Brand Preference: An Experiential View, Brunel Universit y London.

Reighley, C. (2010, May 17). Reighley Group. Retrieved from 6 stages of consumer buying decision process: http://www.reighleygroup.com/2010/05/17/six-stages-of-the-consumer- buying-decision-process/

Sekaran U. \& Bougie R. (2009) Research Methods for Business. John Wiley \& Sons Ltd.

Srivastava, R. And Shocker, A. D. (1991). Brand equity: A perspective on its meaning and measurement. Report Number 91-124. Cambridge: Marketing Science Institute.

Swinker, M. E. \& Hines, J. D. (2005) Understanding consumers' perception of clothing quality: a multidimensional approach. International Journal of Consumer Studies. [Online] 30(2), pp.218-223. Available from: doi.org/10.1111/j.1470-6431.2005.00478.x [Accessed 21st July 2018].

Vakratsas and Ambler (1999) How advertising works; SAGE journal p 26-43

Steenkamp J-B.E. (1997), Dynamics in consumer behavior with respect to agricultural and food products. In Agricultural Marketing and Consumer Behavior in a Changing World. Kluwer Academic Publishers

Statista (2019) Number of Smartphone users worldwide from 2014 to 2020 (in billions).Online Available from: https://www.statista.com/statistics/330695/number-of-smartphone-users- worldwide/

Terence Shimp, J. C. (2013). Advertising Promotion and Other Aspects of Integrated Marketing Communications.

Temporal, P. and Lee, K.C., (2001), Hi-Tech Hi-Touch Branding: Creating Brand Power in the Age of Technology, John Wiley \& Sons, New York, NY.

Ward. S., Light, L. and Goldstine, J.(1999), What high-tech managers need to know what about brands, Harvard Business Review, 77(4), 85-95. School of Commerce. 